\title{
$\begin{array}{llllllllllllllll}\mathbf{S} & \mathbf{T} & \mathbf{U} & \mathbf{D} & \mathbf{I} & \mathbf{A} & \mathbf{I} & \mathbf{M} & \mathbf{A} & \mathbf{T} & \mathbf{E} & \mathbf{R} & \mathbf{I} & \mathbf{A} & \mathbf{L} & \mathbf{Y}\end{array}$
}

KWARTALNIK HISTORII KULTURY MATERIALNEJ 69 (2), 2021

PL ISSN 0023-5881

www.iaepan.edu.pl

the CC BY 4.0 license (https://creativecommons.org/licenses/by/4.0/)

DOI: 10.23858/KHKM69.2021.2.001

\author{
Dariusz Wyczótkowski
}

\section{Średniowieczny kościół Świętego Wojciecha na Zawodziu w Kaliszu — badania i interpretacje}

\begin{abstract}
Abstrakt: Celem artykułu jest przedstawienie informacji o początkach kościoła Św. Wojciecha w Kaliszu funkcjonujących dotychczas w literaturze oraz próba ich weryfikacji. Tytułowa świątynia leży na terenie przygrodowej osady Kalisz Zawodzie. Z uwagi na bliskość grodu oraz wezwanie badacze zaliczali go do najstarszych, jedenastowiecznych kościołów parafialnych w Kaliszu. Powtórna analiza źródeł pisanych pozwoliła na przesunięcie daty jego powstania na XII-XIII w. Z kolei dalsze uściślenie czasu wzniesienia świątyni — po połowie XII w. było możliwe dzięki analizie wyników dawnych i nowszych badań archeologicznych prowadzonych wewnątrz kościoła i na terenie cmentarza przykościelnego. Dostarczyły one dowodów, że budowlę wzniesiono na terenie osady użytkowanej od X do przełomu XII i XIII w.

Abstract: The aim of the paper is to review and verify assumptions about the origins of St Adalbert's church in Kalisz present in the literature. The church was built in the area of the settlement located next to the stronghold; due to this location and the dedication researchers counted it among the oldest 11th-century parish churches in Kalisz. A new analysis of written sources has shown that the church was founded in the 12th-13th c. A more specific dating, after the mid-12th c., is possible thanks to analyzing the results of the newest as well as earlier excavations conducted in the church and around it, which prove that the church was built within a settlement that had functioned from the 10th c. to the turn of the 13th c.
\end{abstract}

Słowa kluczowe: Kalisz, wczesne średniowiecze, kościól, źródła, archeologia

Key words: Kalisz, early-medieval period, church, sources, archaeology

„W stronie zachodniej miasta Kalisza, tuż pod samem miastem, złączona z wsią Stare miasto Kalisz, leży wieś Zawodzie; a w pośrodku niej stoi mały schludny kościołek pod wezwaniem Świętego Wojciecha, wystawiony jak niesie podanie na pamiątkę i na miejscu gdzie ten Święty ogłaszał swoje nauki. Oznaczyć dokładnie czasu założenia tego kościółka oraz jego fundacji i przejść następnych niepodobna; albowiem żadnych akt miejscowych nie posiada, gdyż te wraz z kościołem stały się pastwą płomieni za czasów wojen szwedzkich”’.

Drewniana świątynia Św. Wojciecha, wznosząca się obok grodziska na Zawodziu, jest najmniejszym, a zarazem chyba najbardziej malowniczym kościołem kaliskim. Obecny budynek pochodzi z końca XVIII w. Napis wyrzeźbiony na jednej z belek informuje, iż został on wzniesiony w roku 1789 (ryc. 1).

W wydanej w 2016 r. książce o kościołach diecezji kaliskiej zamieszczono następujące wiadomości: „Kościół usytuowany jest na terenie Zawodzia, a pierwsza informacja zawarta

1 Stawecki E. 1858, s. 35. 


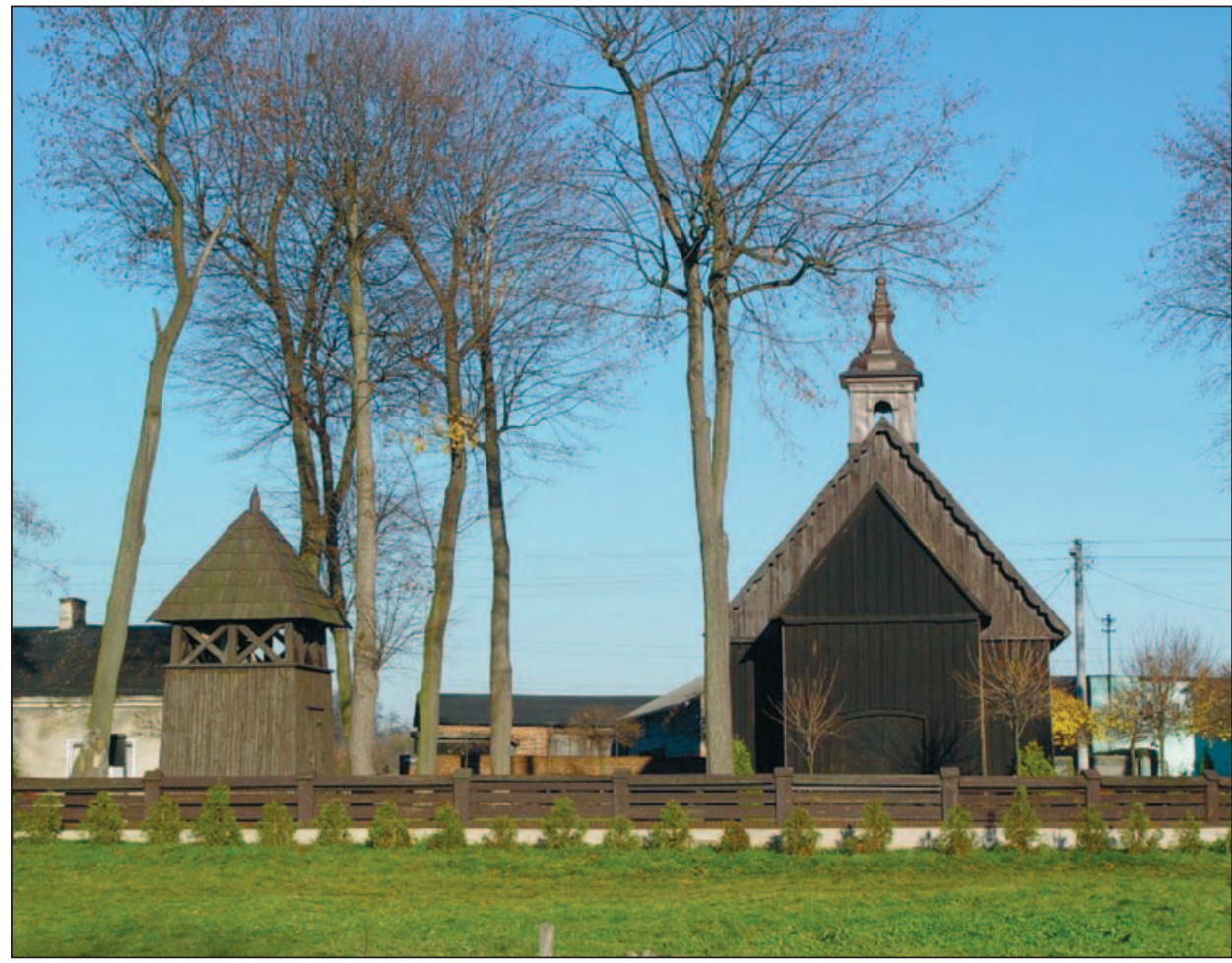

Ryc. 1. Kościół Św. Wojciecha na Zawodziu w Kaliszu, stan obecny (fot. A. Kędzierski)

Fig. 1. St Adalbert's church at Zawodzie in Kalisz, the present condition (photo by A. Kędzierski)

w źródłach pisanych o świątyni św. Wojciecha pochodzi z 1213 roku. Natomiast z nieco późniejszego dokumentu wystawionego w 1292 przez księcia wielkopolskiego Przemysła II, dowiadujemy się, że pełniła ona wówczas funkcję kościoła parafialnego. Parafia zniesiona została w 1406 roku przez arcybiskupa gnieźnieńskiego Mikołaja Trombę, a jej uposażenie oraz kościółek przekazano w zarząd kolegium wikariuszy kolegiaty pw. Wniebowzięcia Najświętszej Maryi Panny w Kaliszu”2. Informacje te powtarzają się zarówno w publikacjach, jak i na portalach poświęconych miastu Kalisz, jego zabytkom i historii w sposób w zasadzie niezmieniony, czasem z dodatkową wzmianką jakoby kościół miał być wzniesiony ok. roku 1200 (Kościół. 2020) lub ok. 1198 (Splitt J.A. 2009).

Pobieżna lektura tych danych wprawia w zakłopotanie i nie jest to związane tylko z brakiem jakichkolwiek odnośników do źródeł, na podstawie których narracja ta została stworzona. Problem tkwi w tym, iż wymieniony w niej biskup w roku 1406 był podkanclerzym królewskim i kanonikiem gnieźnieńskim. Arcybiskupem gnieźnieńskim został dopiero w 1412 r. Drugi wniosek wynikający z lektury przekazów źródłowych dotyczy przedmiotu sprawy, parafii przy kościele Świętego Wojciecha, której najzwyczajniej wtedy nie było.

Żeby zrozumieć, skąd mogły się wziąć te błędy popełniane w licznych współczesnych publikacjach, należy sięgnąć do najwcześniejszych opracowań poświęconych Kaliszowi.

2 Kieling M., Kęszka S., Splitt J.M. 2016, s. 288. 
W pierwszych opisach miasta, zarówno w Starożytnej Polsce ${ }^{3}$ jak i w nieco późniejszym Opisie miasta Kalisza $a^{4}$ nie ma żadnych informacji o kościele. W wieku XIX leżał na odległych peryferiach miasta i być może dlatego nie został uwzględniony w tych pracach.

Pierwszy większy tekst dotyczący kościoła, wraz z ryciną przedstawiającą jego widok, opublikował w 1858 r. kaliszanin, Edward Stawecki, w autorskim wydawnictwie Album Kaliskie $e^{5}$. Oprócz nieco pobieżnego, lecz — co należy przyznać — bardzo malowniczego opisu wyglądu kościoła ${ }^{6}$, Stawecki nie podał wiadomości historycznych o jego przeszłości, tłumacząc się brakiem dokumentów związanym ze zniszczeniem świątyni w czasie wojen szwedzkich. Jednocześnie przekazał ludową opowieść o wizycie świętego Wojciecha na Zawodziu, w trakcie której dojść miało do kradzieży rękawiczki biskupa i klątwie, jaką w złości miał rzucić na mieszkańców wsi7. Kolejne części opisu poświęcił już problemowi grodziska na Zawodziu, identyfikowanemu przez niego ze starożytnym zamkiem księcia Zbigniewa ${ }^{8}$.

W opisie miasta Kalisza, będącym najwcześniejszą monografią miasta, zamieszczonym w „Tygodniku Katolickim” w 1865 r., opisujący historię miasta ksiądz Piotr Kobyliński przytoczył po raz kolejny legendę o świętym Wojciechu, precyzując, iż sytuacja miała miejsce podczas odprawiania mszy w pierwszym kaliskim kościele ${ }^{9}$. Nieco dalej, powołując się enigmatycznie na źródła kapituły kolegiackiej z XIV w. podał, iż są ślady istnienia w roku 1202 kościoła parafialnego pod wezwaniem Świętego Wojciecha ${ }^{10}$. Kobyliński uznał go za najstarszy kościół Kalisza obok kolegiaty Świętego Pawła. W dalszej części artykułu, omawiając organizację kaliskiej kolegiaty w kościele Najświętszej Marii Panny, podał — tym razem bez powoływania się na źródła — iż po przeniesieniu kapituły kolegiackiej do kościoła Panny Marii, kościół Świętego Wojciecha pełnił funkcję parafialną dla Starego Miasta w Kaliszu. Funkcje te miały zostać przekazane wikariuszom kolegiaty za zgodą kapituły przez arcybiskupa gnieźnieńskiego Mikołaja Trąbę w 1406 r. ${ }^{11}$ Artykuł Kobylińskiego, drukowany w trzech częściach w kolejnych numerach czasopisma w tymże roku, uważany był przez lata za pierwszą naukową monografię miasta ${ }^{12}$.

${ }^{3}$ Baliński M., Lipiński T. 1843, wyd. 1; Baliński M., Lipiński T. 1885, wyd. 2 uzupełnione i poprawione, również takich informacji nie zawiera.

${ }^{4}$ Biernacki C.A. 1848.

5 Stawecki E. 1858.

${ }^{6}$ Stawecki np. nie opisał ołtarzy znajdujących się w kościele, podając tylko ich ogólną liczbę i koncentrując się na figurze Św. Wojciecha z ołtarza głównego. Z innych źródeł wiadomo, że aż do 1892 r. ołtarzem głównym w kościele był tzw. poliptyk kaliski, wybitne dzieło warsztatu Mistrza z Gościszowic z końca XV w. Oprócz niego w tym czasie były jeszcze dwa ołtarze boczne.

7 Wydaje się, że miejscowa legenda związana jest ze znajdującą się wówczas w kościele figurą Świętego, umieszczoną wtórnie w centralnej części tzw. poliptyku kaliskiego lub też poliptyku Mistrza z Gościszowic. Ołtarz z figurą jeszcze w XIX w. był na wyposażeniu kościoła Św. Wojciecha na Zawodziu, gdzie trafił zapewne z kaliskiej kolegiaty. W drugiej połowie XIX w. został zabrany z powrotem i wystawiony jest obecnie w bocznej nawie kolegiaty Św. Józefa w Kaliszu. Święty został przedstawiony w pozie błogosławieństwa, z podniesioną prawą ręką. Stawecki przekazał informację o braku rękawiczki na dłoni lewej, trzymającej biskupi pastorał i związaną z tym miejscową legendę o kradzieży rękawiczki przez mieszkańca Zawodzia. Motyw braku tej części stroju Świętego Wojciecha, skradzionego podczas mszy na Zawodziu, wydaje się być wtórną interpretacją średniowiecznej rzeźby, powstałą w miejscowym środowisku. Przedstawienie ikonograficzne świętego bez jednej rękawiczki prawdopodobnie może być związane z legendą zawartą w tzw. Kronice Dalimila (Grzesik R. 2002, s. 52).

${ }^{8}$ Stawecki E. 1858, s. 35.

${ }^{9}$ Kobyliński P. 1865, s. 453.

10 Kobyliński P. 1865, s. 454.

11 Kobyliński P. 1865, s. 456.

12 W świetle dzisiejszej wiedzy, na podstawie opublikowanych dokumentów, wiadomo w jak wielu kwestiach pomylił się Autor, nie przeprowadzając krytyki źródeł i ulegając pokusie literalnego przedstawienia wiadomości z dokumentów kapituły kaliskiej, do których miał dostęp. Zapewne jego renoma znakomitego znawcy historii miasta, a w szczególności znawcy jego instytucji kościelnych sprawiła, że błędy te zostały powtórzone jeszcze wiele razy, a w formie oryginalnej oraz nieco przetworzonej powielane są nadal w publikacjach wydawanych w XXI w. 
Kolejny miejscowy historyk, Adam Chodyński, w artykule opublikowanym w 1872 r., dotyczącym najstarszych dziejów Kalisza, kościół Świętego Wojciecha nazywa „niepamiętnie dawnym”13. Ten nieprzeciętny kaliszanin, wielce zasłużony dla miasta i rozjaśniania mroków jego historii, najprawdopodobniej korzystał z archiwum kościelnego we Włocławku, jak też z dokumentów kaliskiej kapituły kolegiackiej. W swoich tekstach powtórzył kilka informacji przedstawionych we wcześniejszych publikacjach. Jako pierwszy przekazał treść zapisu z 1292 r., w którym Przemysł II daruje plebanowi wieś Sierzchowo ${ }^{14}$. Dokument ten, nieznany obecnie, pod koniec wieku XIX miał się znajdować w archiwum kaliskim. Jest to, jak się wydaje obecnie, najstarsza wzmianka źródłowa poświadczająca istnienie omawianego kościoła.

Informacje powyższe, podawane w miejscowych opracowaniach, nie zostały wykorzystane w Słowniku Geograficznym..., którego autorzy posiłkowali się w opisach dokumentami zawartymi w czterech pierwszych tomach Kodeksu Dyplomatycznego Wielkopolskiego (dalej cyt.: KDW). Przy haśle „Zawodzie” w Słowniku zamieszczono jedynie informacje o tym, że wedle tradycji kościół na Zawodziu ma być najstarszą parafią Kalisza oraz mylną interpretację dokumentu z 1299 r. ${ }^{15}$ o sprzedaniu przez Jaśka, trybuna kaliskiego, ziemi pod zamkiem w celu lokacji wsi ${ }^{16}$. Znacznie więcej wiadomości na temat Zawodzia i kościoła Świętego Wojciecha zawiera hasło „Kalisz” w suplemencie Słownika, w drugiej części tomu XV. Autor hasła tym razem bardzo rzeczowo i skrupulatnie podał dostępne mu dane źródłowe dotyczące Starego Miasta, Zawodzia oraz kaliskich kościołów. Odnośnie do kościoła Świętego Wojciecha przedstawiony został dokument Przemysła II o zezwoleniu na lokację Sierzchowa w 1294 r. oraz informacja z 1299 r. o lokacji wsi Zawodzie ${ }^{17}$.

Z uwagi na zbieżność dat wydania, autorzy Słownika nie mogli zapewne skorzystać z kolejnego artykułu Adama Chodyńskiego poświęconego kościołowi, wydanego w 1901 r. ${ }^{18}$ Chodyński, bez podania źródeł, z których korzystał, przekazał, iż kościół Świętego Wojciecha był od wprowadzenia chrześcijaństwa w Polsce kościołem parafialnym dla dawnego Kalisza. Z kościołem, oprócz proboszcza, związany mógł być — według niego — kler kolegiaty Świętego Pawła. Dalej Autor, jak się wydaje za Kobylińskim, podaje interesującą, choć zarazem nieprawdziwą informację o tym, że w 1406 r. w wyniku przelania praw parafialnych w Starym i Nowym Kaliszu na wikariuszy kolegiaty Najświętszej Maryi Panny przez arcybiskupa Mikołaja Trąbę, do grona kanoników tejże kolegiaty został włączony proboszcz Świętego Wojciecha wraz ze swoim uposażeniem ${ }^{19}$. Jak powyżej wspomniano, Mikołaj Trąba został arcybiskupem gnieźnieńskim dopiero sześć lat później, tj. w roku 1412. Obecnie trudno dociec na jakich, niewątpliwie fałszywych dokumentach wyrażono powyższą opinię. Wiadomo, iż Chodyński korzystał, podobnie jak Kobyliński, z dokumentów zgromadzonych w archiwum kaliskiej kolegiaty. Być może tam właśnie, w środowisku kanoników, powstała zapiska o likwidacji parafii Świętego Wojciecha na Zawodziu i przekazaniu praw parafialnych do kolegiaty. Należy przyznać, iż obaj kaliscy historycy przekazali tę informację w sposób tak sugestywny dla potomnych, że przetrwała ona do dnia dzisiejszego i podawana jest w sposób pewny, a zarazem bezrefleksyjny. Na podstawie tej wzmianki stworzona została wiadomość, iż Mikołaj Trąba zlikwidował parafię świętego Wojciecha ${ }^{20}$.

Monografia Kalisza pióra Józefa Raciborskiego, wydana na dwa lata przed wybuchem pierwszej wojny światowej, sumuje wcześniejsze ustalenia i powtarza jedynie znane już

\footnotetext{
13 Chodyński A. 1872, s. 191.

14 Chodyński A. 1872, s. 191.

15 KDW. 1881, nr 2062.

16 Zawodzie. 1895, w rzeczywistości dokument mówi o lokacji wsi na gruntach Zawodzia.

17 Kalisz. 1902, s. 42 i n.

18 Chodyński A. 1901.

19 Kobyliński P. 1865, s. 456; Chodyński A. 1901, s. 2.

${ }^{20}$ Por.: Błachowicz M. 2008; Kieling M. i in. 2016.
} 
wcześniej dane ${ }^{21}$. Okres międzywojenny nie wniósł w sprawie historii kościoła w zasadzie nic nowego, oprócz pierwszych informacji o pracach archeologicznych na terenie grodziska na Zawodziu.

Dopiero powojenne zainteresowanie archeologów i historyków Kaliszem przyniosło nowe wiadomości i ustalenia. W wydanej w 1956 r. książeczce Kalisz w starożytności i w średniowieczu Teresa Uzdowska opublikowała szkic Kalisz wczesnośredniowieczny ${ }^{22}$. W tekście podano kilka informacji o kościele Świętego Wojciecha. Autorka stwierdziła m.in. iż był to kościół parafialny przeznaczony dla osady podgrodowej znajdującej się na terenie Zawodzia. Jego początek, na podstawie analizy wezwania, upatrywała już w XI stuleciu. W tekście dotyczącym świątyni podała, iż pierwsza wzmianka źródłowa o niej pochodzi z 1213 r., gdy w dokumencie źródłowym został określony jako ecclesia sancti Adalberti ${ }^{23}$. Niestety Autorka nie podała, skąd cytat miałby pochodzić. Jedyny tekst źródłowy z 1213 r. związany z Kaliszem, ale tylko przez miejsce jego wydania i jego świadków, jest dokumentem Władysława Odonica poświadczającym nadania dla klasztoru w pobliskim Ołoboku ${ }^{24}$. Wśród świadków darowizny znaleźli się Bodo, prepozyt kolegiaty kaliskiej oraz jej dziekan Wit. Pomimo niejasnego pochodzenia zapisu przytaczanego przez Uzdowską, ta właśnie data będzie się pojawiać w niektórych opracowaniach dotyczących kościoła Świętego Wojciecha jako datowanie pierwszej wzmianki źródłowej.

Na początku lat sześćdziesiątych ubiegłego wieku zostały opublikowane trzy tomy wydawnictwa związanego z obchodami XVIII wieków Kalisza, świętem miasta nawiązującym do zagadkowej notatki Ptolemeusza, wspominającego miejscowość zwaną Kalisia, leżącą na tzw. Szlaku Bursztynowym² ${ }^{25}$. W pierwszym tomie publikacji z 1960 r. Teresa Wąsowicz zamieściła znakomity artykuł ukazujący miejsce Kalisza na tle wczesnośredniowiecznej sieci drożnej. W artykule tym, w przypisie 65, analizując wezwania kaliskich kościołów zauważyła, iż kościół świętego Wojciecha należy wraz kościołem Najświętszej Maryi Panny do najstarszych fundacji związanych z grodem na Zawodziu ${ }^{26}$. W tym samym tomie znalazł się również artykuł Marty Młynarskiej, omawiający problematykę procesu lokacji Kalisza w XIII i połowie XIV w. W przypisie 11, odnosząc się do kościoła Świętego Wojciecha, przedstawione zostały niektóre dostępne przekazy źródłowe oraz teza, iż powstanie świątyni należałoby wiązać z rozwojem kultu Świętego w końcu XI i na początku XII stulecia. Jednocześnie Autorka wysunęła przypuszczenie, iż mogła to być fundacja rycerska ${ }^{27}$.

Kolejna publikacja ukazała się w trzecim tomie Osiemnastu wieków Kalisza, w roku 1962. Jest to znakomity artykuł Stanisława Trawkowskiego — analiza kształtowania się regionu kaliskiego i kaliskiego ośrodka osadniczego. Przy okazji omawiania problemu lokalizacji targu, znanego z falsyfikatu lubińskiego ${ }^{28}$, Autor wspomniał, że kościół Świętego Wojciecha był zapewne najstarszym kościołem kaliskim fundacji monarszej, o czym ma świadczyć m.in. fakt późniejszego nadania Zawodzia przez księcia na rzecz rycerza Peregryna ${ }^{29}$.

Do dyskusji nad początkiem kościoła Św. Wojciecha włączył się także badacz Zawodzia i odkrywca kaliskiej kolegiaty, Krzysztof Dąbrowski. Na podstawie wyników własnych prac wykopaliskowych, przeprowadzonych w otoczeniu świątyni w 1959 r., początkowo datował jej

21 Raciborski J. 1912, s. 11, 18.

22 Uzdowska T. 1956.

23 Uzdowska T. 1956, s. 51.

${ }^{24}$ KDW. 1877, nr 81.

${ }^{25}$ Dyskusję na temat Kalisii Ptolemeusza podsumowali Jerzy Kolendo (Kolendo J. 2010a; Kolendo J. 2010b) oraz Tadeusz Baranowski (Baranowski T. 2010).

${ }^{26}$ Wąsowiczówna T. 1960, s. 101.

27 Młynarska M. 1960, s. 124.

${ }^{28}$ KDW. 1877, nr 368.

29 Trawkowski S. 1962, s. 26; s. 45, przyp. 108. 
powstanie na wiek XII, natomiast znalezione w trakcie badań wyroby ceramiczne na przełom XI i XII w..$^{30}$ Wydaje się jednak, iż było to raczej związane z przeświadczeniem o wczesnej metryce kościoła, niż z analizą zabytków porównywalnych do znajdowanych równie licznie na pobliskim grodzisku. W nieco późniejszej publikacji tego Autora zamieszczona została informacja, iż znaleziska pozyskane w trakcie badań przy kościele pochodzą z okresu od przełomu IX i X do przełomu XI i XII w., zaś pierwsze pochówki z przełomu XII i XIII w. ${ }^{31}$ W jednym z ostatnich swoich artykułów na temat Kalisza we wczesnym średniowieczu Krzysztof Dąbrowski zmienił zdanie po raz kolejny i datował powstanie kościoła na początek XI stulecia, całkowicie już pomijając rezultaty swoich badań archeologicznych ${ }^{32}$.

Andrzej Wędzki, w artykule zamieszczonym w tej samej publikacji zbiorowej, również opowiedział się za możliwością powstania kościoła w wieku $\mathrm{XI}^{33}$. Jednocześnie podał nieprawdziwą datę wzniesienia obecnej świątyni, która miałaby być zbudowana - według niego w 1198 r. Przypuszczać jedynie można, iż jest to zapewne pomyłkowo zapisana przez Wędzkiego, i nie skorygowana w trakcie prac nad tekstem, data wybudowania obecnego drewnianego kościoła, który wzniesiono w roku 1798. Data podana przez A. Wędzkiego funkcjonuje nadal, przekazywana bezrefleksyjnie w popularnych opracowaniach na temat historii kościoła ${ }^{34}$.

Jak widać, wszystkie dane dotyczące kościoła umieszczone zostały w tekstach omawiających szerszą problematykę, w sposób niemalże marginalny. Mimo to, przez następne lata stanowiły one podstawę analiz i formułowanych hipotez. W publikacjach współczesnych szczególnie często, jak wspomniano powyżej, pojawia się nawet pozbawiony jakichkolwiek podstaw źródłowych wątek o parafialnej funkcji kościoła oraz o zlikwidowaniu parafii w 1406 r. przez arcybiskupa gnieźnieńskiego, Mikołaja Trąbę ${ }^{35}$.

Jak naprawdę wyglądała historia kościoła Świętego Wojciecha trudno dociec. Pewnym jest, iż na dotychczasowych publikacjach zaciążyło przywiązanie autorów do założonej z góry tezy o jego wczesnej fundacji, sformułowanej na analizie wezwania. Starożytność kościoła była więc swego rodzaju osnową, na której konstruowano opowieść o jego losach, używając do tego celu znanych faktów.

Co zatem można powiedzieć obecnie o kościele Świętego Wojciecha?

Najwcześniejsze źródła pisane wspominające świątynię z kaliskiego Zawodzia pochodzą z lat dziewięćdziesiątych XIII w. Pierwszym jest niezachowany dokument Przemysła II, w którym książę obdarowuje kościół wsią Sierzchów. Dokument miał pochodzić z roku 1292. W 1872 r. przechowywany miał być w archiwum kaliskim ${ }^{36}$. Józef Raciborski, pisząc swoją Monografię Kalisza w 1912 r., dokument ten umiejscawia w Archiwum Akt Dawnych w Warszawie ${ }^{37}$. Co wydaje się interesujące, to nie uwzględniają go wydawcy KDW, zarówno redaktorzy tomów I-V, jak i tomów VI-XI, wydawanych od 1982 do 1999 r. Problem autentyczności tego dokumentu stoi niejako w opozycji z ogólnie przyjętym założeniem, iż przekazanie całego Zawodzia, a więc zarówno grodziska, jak i związanej z nim osady, nastąpiło ok. roku 1284.

Niestety nie znany jest dokument poświadczający samo nadanie. W wyniku analizy treści zachowanych archiwaliów wydaje się, iż nadanie Zawodzia prywatnym właścicielom mogło nastąpić dopiero w końcu XIII w. Wbrew wydawcom pierwszego tomu KDW sądzę, iż nie

30 Dąbrowski K. 1962, s. 85.

31 Dąbrowski K., Gieysztor A. 1964, s. 353.

32 Dąbrowski K. 1977, s. 36.

33 Wędzki A. 1977, s. 59.

34 Splitt J.A. 2009.

35 Kieling M. i in. 2016, s. 288; Błachowicz M. 2008, s. 24.

${ }^{36}$ Chodyński A. 1872, s. 191, przyp. 6. Autor umiejscawia dokument w spisie „Acta inser, Castr. Caliss. an. 1544, p. 933”, w Archiwum Kaliskim.

37 Raciborski J. 1912, s. 18, przyp. 1, „Acta inser. Castr. Caliss. A. 1544, pag 933” w Archiwum Akt Dawnych w Warszawie. 
można dokumentu Przemysła II z roku 1285 (1286) $)^{38}$, potwierdzającego i rozszerzającego nadania na terenie Dobrzeca Małego, rozciągać na Zawodzie. Dokument wyraźnie wymienia jedynie posiadłości Jaśka, podstolego na dworze księżnej, leżące na zachodnim brzegu doliny Prosny, naprzeciwko Zawodzia. Pomyłka wydawców wydaje się wynikać z nikłej wiedzy na temat topografii Kalisza. Podgórze, wielokrotnie tłumaczone w dokumentach Kodeksu jako Zawodzie, w rzeczywistości jest częścią obecnego Kalisza, na skłonie wysoczyzny na lewym brzegu doliny, naprzeciwko miasta lokacyjnego, czyli ok. kilometr na północ od Zawodzia, leżącego na dnie doliny Prosny.

Wydawcy czwartego tomu KDW, w omówieniu dokumentu nr $2062^{39}$, na potwierdzenie darowizny Zawodzia dla synów Peregryna przywołali publikację Piotra Kobylińskiego z 1865 r., nazywaną nawet Monografia Kalisza. Wbrew temu, co wydawcy dokumentu napisali, nie wnosi ona nic nowego. Kobyliński zdaje się swoje informacje odnosić nie do jakiegoś zaginionego aktu darowizny na rzecz Peregryna a właśnie do dokumentu z 1294 r., który prawdopodobnie jest tożsamy z dokumentem zamieszczonym w KDW, w tomie drugim, nr $714^{40}$, wspominającym synów Peregryna jako dziedziców Zawodzia i patronów kościoła Św. Wojciecha ${ }^{41}$. Szukając dalej wskazówek dotyczących darowizny Zawodzia, należy również zauważyć, że Przemysł II, wymieniając w dokumencie z 1290 r. posiadłości darowane synom Peregryna, nie uwzględnia wśród nich Zawodzia ${ }^{42}$.

Dla określenia czasu, gdy Zawodzie stało się włością rycerzy z Grabianowa, istotne wydają się zwłaszcza wzmianki o funkcjonowaniu kolegiaty św. Pawła, na znajdującym się tuż obok grodzie jeszcze w latach $1285^{43}$ i $1291^{44}$. Według mnie, jednoznacznie świadczy to, iż gród, a zapewne także i osada z nim związana, pozostawały jeszcze w ręku księcia.

Jak wspomniałem, nie jest znany dokument darowizny Zawodzia. Peregryn z Grabianowa, który według wydawców KDW miałby zostać obdarowany zarówno grodem, jak i osadą Zawodzie, pojawia się w dokumentach dopiero jako wspomniany z imienia ojciec jego właścicieli. Pierwszy raz wspomniany został w cytowanym powyżej dokumencie Przemysła II z roku $1290^{45}$. Podniesiono w nim zasługi Peregryna przy odzyskiwaniu kaliskiego zamku, zapewne w 1284 r. z rąk Sędziwoja z rodu Zarembów, który działał na rzecz księcia śląskiego, Henryka IV Probusa. Dalej wymienionych jest szereg posiadłości potomków Peregryna lecz, jak to wyżej zaznaczono, bez kaliskiego Zawodzia. Z kolei dokument z roku 1294, wystawiony przez Przemysła II dla rektora kościoła Św. Wojciecha i zezwalający na lokację wsi w Sierzchowie ${ }^{46}$, poświadcza pośrednio, że Zawodzie było własnością synów Peregryna z Grabianowa.

Uznając autentyczność zaginionego dokumentu Przemysła II z 1292 r., jak również darowiznę wsi Sierzchów przez księcia dla kościoła, można przyjąć, iż sam kościół wówczas pozostawał jeszcze w rękach księcia wraz z całym Zawodziem.

Świątynia pod wezwaniem św. Wojciecha pojawia się też w 1294 r., we wspomnianym już dokumencie Przemysła II z 27 maja, zezwalającym na lokację wsi na gruntach Sierzchowa ${ }^{47}$

${ }^{38}$ Przez wydawców KDW dokument ten jest datowany na rok 1285 (KDW. 1877, s. 553). Uwagi co do błędnej daty wysunął S. Krzyżanowski, ustalając, że został on wystawiony w 1286 r. (Krzyżanowski S. 1890, s. 168).

39 KDW. 1881, nr 2062.

${ }^{40}$ KDW. 1878, nr 714.

41 Kobyliński P. 1865, s. 454.

${ }^{42}$ KDW. 1982, nr. 40.

43 KDW. 1877, nr. 554, wśród świadków dokumentu arcybiskupa gnieźnieńskiego Jakuba Świnki występuje Miroslao preposito Kalisiensi.

${ }^{44}$ KDW. 1878. nr 664, świadkiem dokumentu Przemysła II jest Miroslao preposito sancti Pauli in Kalis.

45 KDW. 1982, nr 40.

${ }^{46}$ KDW. 1878, nr 714.

47 KDW. 1878, nr 714. 
oraz w datowanym na 24 maja dokumencie lokacyjnym wsi Sierzchów ${ }^{48}$. Drugi z dokumentów wystawiony został przez Włosta, syna Wyszoty, rektora kościoła Św. Wojciecha.

Wynika z nich, iż Zawodzie stanowiło już włość rycerską. Co ważne, w obu tych dokumentach mowa jest o rektorze. Tytulatura ta, używana w stosunku do kapłana związanego z tym obiektem, pojawia się także i w innych, późniejszych źródłach. Wprawdzie w 1299 r. w dokumencie lokacyjnym wsi Zawodzie występuje pleban kościoła, jednak można przyjąć, że w tym przypadku chodzi o ogólne określenie osoby, dla której należny będzie czynsz płacony z poszczególnych zagród lokowanej wsi ${ }^{49} .8$ lipca 1339 r. Piotr, rektor kościoła Świętego Wojciecha, sprzedał role Brzezie i Żądłowo (Sadłowo?) kmieciom z Rajskowa ${ }^{50}$. W dokumencie tym jego wystawca stosuje wobec swojej osoby, jak i wobec swoich następców, konsekwentnie tytulaturę rector ecclesiae Sancti (Beati) Adalberti.

Według mnie tych kilka przykładów jednoznacznie poświadcza funkcję kościoła i wskazuje, iż pozostając na terenie parafii Najświętszej Maryi Panny nie pełnił on funkcji świątyni parafialnej. Dodatkowym potwierdzeniem tego faktu jest dokument wystawiony przez arcybiskupa Jarosława Bogorię ze Skotnik w 1359 r. ${ }^{51}$ Arcybiskup oświadcza, posiłkując się zeznaniem rektora kościoła Św. Wojciecha, prepozyta kaliskiego Jana, iż prawa parafialne kościoła Najświętszej Maryi Panny z miasta lokacyjnego rozciągają się na wsie Rajsków i Noskowo, a także na tereny położone przy kościele Św. Wojciecha ${ }^{52}$. O prawach tych rektor Św. Wojciecha mówi w sposób stanowczy: [...] iure parochiali et parochialiter pertinuerant et pertinebant ab antiquo [... $]^{53}$. Wydaje się, iż wystawiony w 1359 r. dokument niejako uzupełnia podział kaliskiego ośrodka pomiędzy dwie kaliskie parafie, dokonany w 1303 r. przez arcybiskupa Jakuba Świnkę ${ }^{54}$. W świetle dokumentów, kościół Świętego Wojciecha powstał więc najpóźniej w końcu XIII stulecia na terenie objętym prawem parafialnym kościoła Najświętszej Maryi Panny. Nie uzyskał nigdy praw parafialnych i pozostawał kościołem rektorskim, pełniącym określone funkcje duszpasterskie dla ludności zamieszkałej na Zawodziu.

Dodatkowych danych na temat czasu fundacji kościoła dostarczyły wyniki badań archeologicznych. Pierwsze prace w otoczeniu kościoła pod kierunkiem Krzysztofa Dąbrowskiego przeprowadzono w roku 1959, wykonując cztery wykopy na terenie cmentarza przykościelnego oraz trzy dalsze w jego otoczeniu. Wyniki badań nie zostały opracowane. Jak można sądzić na podstawie ówczesnej dokumentacji terenowej, nie wszystkie wykopy zostały dokopane do calca. Tak było m.in. zapewne w przypadku wykopu nr 1, zlokalizowanego po zachodniej stronie kościoła. W 2013 r. Leszek Ziąbka przeprowadził nadzór archeologiczny w trakcie prac konserwatorskich $^{55}$. Prace polegały na osuszaniu i naprawie fundamentów. Nadzorowi podlegał wykop wykonany wzdłuż fundamentu, o szerokości ok. 0,5 m. Kolejne prace rozpoznawcze w kościele i jego otoczeniu przeprowadzili Adam Kędzierski i Dariusz Wyczółkowski w 2017 i 2018 r., zakładając łącznie cztery wykopy we wnętrzu świątyni i jeden na terenie cmentarza przykościelnego (ryc. 2). W trakcie badań wykopaliskowych, zarówno w 1959 r., jak i później,

48 KDW. 1999, nr 1714.

49 KDW. 1881, nr 2062.

50 KDW. 1999, nr 1725.

51 KDW. 1881, nr 2067

52 Parafii Najświętszej Maryi Panny w Kaliszu podlegają: [...] omnes et singulos predictorum ortorum cultores, inhabitatores seu ortulanos in Rayskow, sito super Prossna flumen iuxta Antiquam Kalisz, et specialiter iuxta seu prope ecclesiam sancti Adalberti, et eiusdem ecclesie rectori racione temporalis dominii censum solventes omnes et singulos hortulanos, nec non medietatem civitatis nove Kalisz, prout in litteris felicis recordacionis quondam domini Iacobi archiepiscopi, predecessoris nostri, desuper confectis plenius continetur, ac eciam Nosskowo villam nostram [...], KDW. 1881, nr 2067.

53 KDW. 1881, nr 2067.

54 KDW. 1878, nr 876.

55 Ziąbka L., Kędzierski A. 2016. 


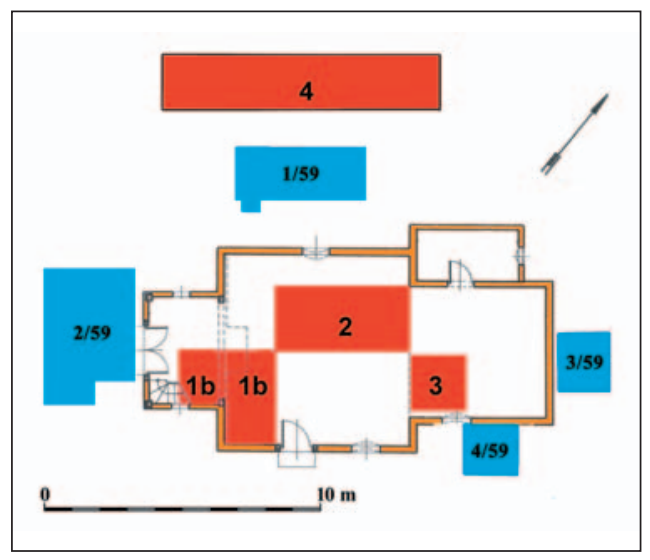

Ryc. 2. Kalisz-Zawodzie. Wykopy badawcze przy kościele Św. Wojciecha:

kolor niebieski — wykopy z 1959 r.; kolor czerwony — wykopy z lat 2017-2018 (oprac. D. Wyczółkowski)

Fig. 2. Kalisz-Zawodzie. Excavation trenches near St Adalbert's church: blue - trenches from 1959; red - trenches from 2017-2018 (prepared by D. Wyczółkowski)

odkryto pozostałości cmentarza przykościelnego. Badania z lat 2017-2018 ujawniły poza tym, iż obecna drewniana świątynia wzniesiona została na miejscu zajmowanym wcześniej przez cmentarz grzebalny. We wszystkich czterech wykopach założonych we wnętrzu obecnej świątyni odsłonięto pochówki szkieletowe. Nie natrafiono przy tym na ślady wcześniejszego obiektu. Zaobserwowano jedynie warstwy gruzu wyrównujące teren cmentarza. Niewątpliwie był to materiał rozbiórkowy. Warstw takich nie stwierdzono w wykopie na zewnątrz kościoła oraz w wykopach z roku 1959. Warstwa ta składała się z fragmentów cegieł oraz z zaprawy wapiennej. Można przypuszczać, iż powstała ona w wyniku rozbiórki fundamentów poprzedniego założenia ${ }^{56}$. Ława fundamentowa obecnego kościoła, wzniesiona na warstwie spojonych gliną kamieni, zbudowana została również przy użyciu cegieł rozbiórkowych.

Istnieje jednak jeszcze inna możliwość. W 1783 r., czyli kilkanaście lat przed budową nowego kościoła na Zawodziu, zawaliła się część kolegiaty Najświętszej Marii Panny w Kaliszu. Jak już wspomniano, kościół Świętego Wojciecha leżał na terenie parafii kolegiackiej. Tutaj też mogła trafić część gruzu ze zniszczonego katastrofą budowlaną kościoła" ${ }^{57}$, użyta do niwelacji terenu. Wydaje się, że może o tym świadczyć zniszczony nagrobek, zastosowany jako przedproże przy bocznym wejściu do kościoła ${ }^{58}$. Możliwe jest też, iż niewielki zasięg warstwy gruzu koncentrującej się w pobliżu obecnego prezbiterium, świadczy również o jego związku z rozbiórką ceglanych fundamentów wcześniejszego kościoła.

Trudno zatem dokładnie określić pochodzenie cegieł w warstwie niwelacyjnej. Podobne cegły użyte zostały w fundamencie obecnego założenia; to cegły rozbiórkowe gotyckie oraz ceramiczne płytki podłogowe. Inne obserwacje poczynione w trakcie badań, m.in. dotyczące zmiany układu pochówków w stosunku do obiektu z XVIII w., analiza strefy zagęszczenia wkopów grobowych, położenia grobów dziecięcych, zdają się wskazywać, iż wcześniejszy budynek kościoła mógł być wzniesiony wzdłuż osi północny zachód-południowy wschód i znajdował się obok dzisiejszej świątyni. W wykopie nr 3/18 stwierdzono, obok pochówków w charakterystycznym, rzędowym układzie jam grobowych, także groby dziecięce. Były to co

${ }^{56}$ Na terenie grodziska również pozyskiwano cegłę rozbiórkową, m.in. z wczesnogotyckiej wieży obronnej znajdującej się na koronie południowo-zachodniego odcinka wałów.

${ }^{57}$ Odbudowę kolegiaty najświętszej Marii Panny w Kaliszu prowadzono w latach 1790-1792(?), przy czym jeszcze w 1796 r. kościół nie był do końca wyposażony, skoro trafiły do niego elementy (m.in. ołtarze) z kościoła pojezuickiego zajętego przez gminę protestancką.

${ }^{58}$ Kilka fragmentów tego nagrobka (manierystycznego epitafium) znaleziono w trakcie nadzoru w 2012 r. Jego wielkość i budowa wskazują, iż pierwotnie był wmurowany w ścianę obiektu sakralnego. Z dużym prawdopodobieństwem można przyjąć, że był to kościół Najświętszej Marii Panny w mieście lokacyjnym. 
najmniej cztery pochówki dzieci w wieku niemowlęcym (wczesny Infans I) oraz liczne kości z innych, rozproszonych pochówków dziecięcych (w wieku Infans I). Obserwowany jest zwyczaj chowania dzieci, szczególnie nowonarodzonych, wzdłuż ścian kościoła ${ }^{59}$. Przypuszczam, iż lokalizacja tych grobów może być związana z bliskością wcześniejszej świątyni ${ }^{60}$.

Poniżej warstwy grzebalnej związanej z funkcjonowaniem cmentarza, zarówno w trakcie badań w 1959 r., jak i późniejszych, odsłonięto zniszczone obiekty z okresu wczesnego średniowiecza oraz fragmentarycznie zachowaną warstwę kulturową. Na podstawie przeprowadzonej analizy znalezionych fragmentów naczyń ceramicznych oraz monet, osadnictwo wczesnośredniowieczne na tym terenie można datować na okres od połowy X do XII-XIII w. Krzysztof Dąbrowski ceramikę pozyskaną podczas swoich badań datował na przełom XI i XII w. ${ }^{61}$ Jak się obecnie wydaje, szczególnie po przeprowadzeniu ponownej analizy zabytków odkrytych w 1959 r., związane to było raczej z przeświadczeniem o wczesnej metryce kościoła i próbą pogodzenia informacji uzyskanych ze źródeł z datowaniem materiałów archeologicznych. Jest to tym bardziej prawdopodobne, iż jak wspomniałem powyżej, Badacz w kolejnych opracowaniach próbował zmienić datowanie znalezisk, dopasowując je do przyjętej koncepcji ${ }^{62}$. Należy przy tym zauważyć, iż odkryte przez niego pochówki nie posiadały żadnego wyposażenia, które pozwoliłoby na ich precyzyjne datowanie, a tym samym na określenie czasu fundacji kościoła. Obecnie, analizując zabytki pochodzące ze wszystkich prac przy kościele Św. Wojciecha oraz porównując z materiałami znanymi z terenu grodu na Zawodziu i z osady Stare Miasto, najwcześniejsze wyroby ceramiczne można datować na drugą połowę X w. Są to głównie fragmenty naczyń lepionych, grubościennych. Wykonano je z glin żelazistych, z dużą domieszką tłucznia granitowego. Ze względu na rozdrobnienie materiału można tylko ogólnie stwierdzić, iż były to formy esowate o wylewach prostych, lekko wychylonych na zewnątrz, zdobione ornamentem zwielokrotnionej linii falistej. Fragmenty te stanowią ok. 20\% znalezisk z okresu wczesnego średniowiecza. Znajdowane były głównie w warstwie grzebalnej cmentarzyska, gdzie trafiły zapewne z obiektów zniszczonych wkopami grobowymi. Według analizy zapisanych metryczek, w 1959 r. zabytki takie pozyskano w wykopie 2 z obiektu wczesnośredniowiecznego i związanego z nim paleniska. W trakcie ostatnich badań, w wykopie nr 1/17, znaleziono również kilka ułamków tego typu ceramiki w warstwie kulturowej i wewnątrz związanego z nią obiektu, datowanego na XI-XII w. (ryc. 3).

Datowanie materiałów na połowę X stulecia zdaje się potwierdzać rozproszony depozyt dirhemów odnaleziony w 2018 r., wiązany z najstarszą fazą zasiedlenia tego terenu we wczesnym średniowieczu ${ }^{63}$. W przypadku późniejszej ceramiki są trudności w jej precyzyjnym datowaniu. O ile materiały z XI i XII w. można rozróżnić między sobą, to problem ten dotyczy wyrobów garncarskich z XII i XIII w. Jest to również problem istotny dla określenia czasu fundacji kościoła. Według źródeł pisanych świątynia mogła być wzniesiona między połową XII a końcem

59 Problem pochówków dziecięcych zlokalizowanych przy ścianach kościoła od dawna poruszany jest w literaturze (por. np. Ulrich-Bochsler S. 1996, s. 165; Unger J. 2002, s. 86; Craig-Atkins E. 2014; Hausmair B. 2017; Crow M. i in. 2020, s. 14). Najbardziej popularny jest pogląd, iż są to pochówki dzieci nieochrzczonych, których miała obmywać woda deszczowa skapująca z dachu kościoła. Wydaje się jednak, ze względu na rygorystyczne przepisy kościelne, dotyczące chowania osób nieochrzczonych na poświęconym miejscu (np. Delimata M. 2004, s. 100-101), że problem ten jest bardziej złożony. Analizę problematyki i konieczność nowego, metodycznego podejścia przedstawiła ostatnio Barbara Hausmair (Hausmair B. 2019).

${ }^{60} \mathrm{~W}$ trakcie prac wykopaliskowych w 2017 i 2018 r. stwierdzono pochówki dzieci tylko w wykopie 3/18. W pozostałych wykopach ani pochówków dzieci w wieku Infans I, ani pojedynczych kości dziecięcych nie znaleziono. Wskazuje to jednoznacznie na związany z tym konkretnym miejscem zwyczaj grzebania niemowląt. Sądzę, że jedynym wythumaczeniem tego faktu jest praktykowany na tym cmentarzu zwyczaj chowania niemowląt w pobliżu świątyni. Bardzo czytelny układ rzędowy pozostałych grobów również świadczy o bliskości kościoła.

${ }^{61}$ Dąbrowski K. 1962, s. 85.

${ }^{62}$ Dąbrowski K., Gieysztor A. 1964, s. 353.

${ }^{63}$ Kędzierski A. i in. 2020, s. 26. 


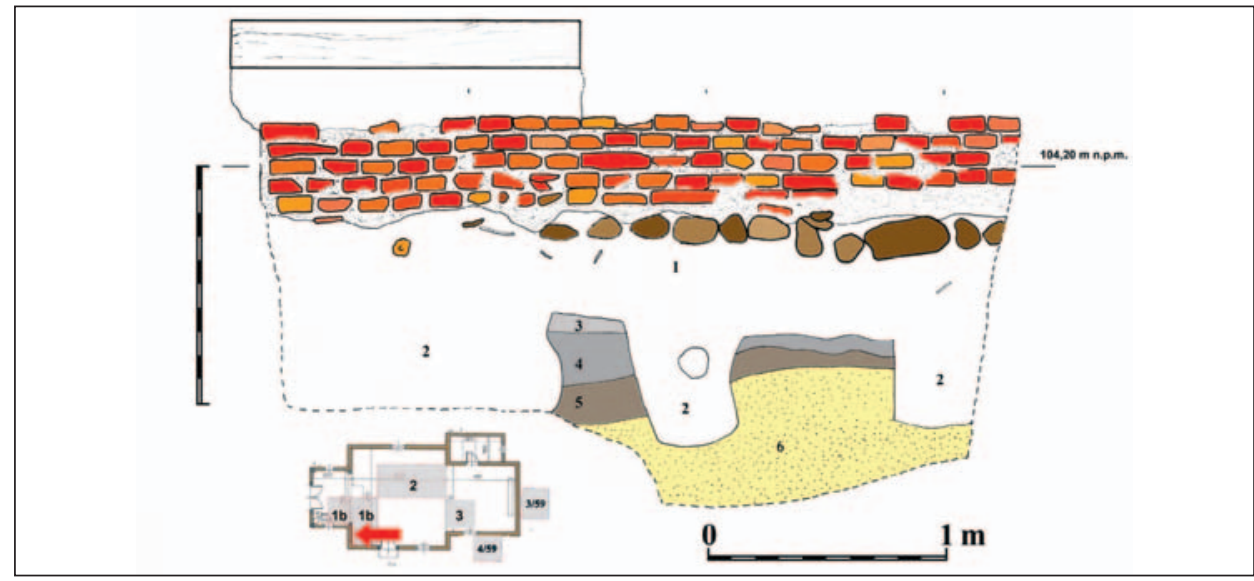

Ryc. 3. Kalisz-Zawodzie. Profil wykopu 1/2017: 1 - warstwa grzebalna; 2 - wkopy grobowe;

3 - warstwa kulturowa; 4 - wypełnisko jamy obiektu z okresu wczesnego średniowiecza; 5 - warstwa użytkowa obiektu; 6 - piaski calcowe (oprac. D. Wyczółkowski)

Fig. 3. Kalisz-Zawodzie. The profile of trench 1/2017: 1 — the burial layer; 2 — burials; 3 - the cultural layer; 4 - the fill of an early-mediaeval feature; 5 - the functional layer of the feature; 6 - natural-soil sand (prepared by D. Wyczółkowski)

XIII w. Pozyskane w trakcie badań terenowych zabytki ruchome pochodzą w większości z warstwy grzebalnej. Nie można więc prowadzić analizy statystycznej, która przy odpowiednim doborze analizowanych cech może wskazać chronologiczne rozróżnienie zespołów.

Jak wykazała analiza znalezisk z badań grodziska na Zawodziu, wyroby ceramiczne z XII i XIII w. nie wykazują większych różnic. Przyjmuje się, iż w XIII stuleciu stosowano więcej form stylistycznie doskonalszych, cienkościennych. Typy i technologia wykonania naczyń w wieku XII oraz spotykanych na osadach związanych z grodem na Zawodziu praktycznie pozostają niezmienione przez następne stulecie i znajdowane są w kontekście dobrze datowanych zabytków z XIII w. Materiały takie stanowią znaczny odsetek ceramiki pozyskanej w trakcie badań przy kościele. Wskazuje to na intensywne osadnictwo w XII w. Są to różnorodne typy naczyń baniastych, naczyń szerokootworowych z wysoko umieszczonym załomem brzuśca oraz naczyń z cylindryczną szyjką. Te ostatnie są charakterystyczne raczej dla XI i XII w. niż dla wieku XIII. Ceramika cienkościenna stanowi niewielką część wśród naczyń o grubszych ściankach. Jak się więc wydaje na podstawie znalezisk archeologicznych, dopiero w XIII czy ewentualnie (przyjmując najwcześniejszą możliwą datę) w ciągu XII w. w tym miejscu mógł być lokowany kościół dla mieszkańców osady Zawodzie.

Datowanie to zgadza się z analizowaną powyżej treścią dokumentów pisanych. Jednakże zasadniczo odbiega od treści większości dotychczasowych publikacji naukowych. Niewątpliwie, na wczesnym datowaniu początków kościoła zaważyła chęć powiązania wezwania świątyni z tzw. pierwszą falą rozwoju kultu św. Wojciecha. Ożywienie tego kultu, związane z odbudową katedry gnieźnieńskiej w XII w., mogło być impulsem dla wezwania kościoła na kaliskim Zawodziu. Jeszcze bardziej interesująca wydaje się możliwość powiązania fundacji świątyni z osobą Mieszka Starego. Ze źródeł pisanych znany jest fakt zaangażowania się Mieszka w odbudowę katedry w Gnieźnie ${ }^{64}$. Wiadomym jest również, iż w drugiej połowie XII w. na grodzie na Zawodziu zosta-

${ }^{64}$ W Kronice Wielkopolskiej znalazł się zapis o ufundowaniu przez Mieszka Starego pokrycia dachu katedry gnieźnieńskiej ołowianymi płytami (Kronika Wielkopolska. 1970, s. 55). O uposażeniu kantora gnieźnieńskiego przez Mieszka Starego, KDW. 1877, nr 47. 
je wzniesiona kolegiata Św. Pawła, zaś gród staje się siedzibą książęcą. Bardzo prawdopodobna wydaje się w związku z tym fundacja kościoła, który miałby przejąć funkcje duchowej obsługi ludności zamieszkującej przygrodową osadę.

Kościół i przykościelny cmentarz był użytkowany do czasów współczesnych, o czym świadczą zabytki znajdowane na cmentarzysku. W XV-XVII w. przy kościelnym cmentarzu znajdował się obiekt mieszkalny, którego ślady odkryto w trakcie badań w 2018 r. Wśród zabytków z dotychczasowych badań notowano również ceramikę nowożytną. Podczas badań archeologicznych w 1959 r. znaleziono ją zarówno w warstwie grzebalnej cmentarza, jak i w wykopach ulokowanych poza jego obrębem. Stanowi ona niemal 40\% wszystkich pozyskanych wyrobów ceramicznych, z tym, że większość fragmentów naczyń nowożytnych (ok. 70\%) znaleziono w dwóch wykopach ulokowanych poza obrębem cmentarza przykościelnego. W jednym z nich prawdopodobnie odsłonięto nawarstwienia odnoszące się do obiektu mieszkalnego stojącego w pobliżu kościoła. Wśród ceramiki nowożytnej przeważają wyroby wypalane w atmosferze utleniającej, jedynie niewielki procent stanowią siwaki. W czasie najnowszych badań, ceramikę z tego czasu znajdowano zarówno w wypełnisku warstwy grzebalnej, jak i w nawarstwieniach związanych z użytkowaniem obiektu odkrytego w południowo-zachodniej części obecnego cmentarza. Ułamki znalezione w warstwach użytkowych umożliwiają datowanie tego obiektu na XVI-XVII w. W wyniku prac ujawniono, iż obiekt ten znajdował się pierwotnie na skłonie kościelnego wzgórza. Ustalono również, iż miał wcześniejszą fazę użytkowania, datowaną na okres od XV w. Wydaje się także, iż ten najwcześniejszy obiekt został zniszczony częściowo w trakcie powodzi. Na tym samym miejscu powstał obiekt kolejny, funkcjonujący do ok. XVII w., potem zaś został rozebrany i zasypany warstwą piasku. Prawdopodobnie chodziło o poszerzenie przykościelnego cmentarza w kierunku zachodnim i południowym, poprzez powiększenie wzniesienia, na którym stał kościół. Świadczą o tym liczne pochówki wkopywane w warstwy niwelacyjne i niszczące nawarstwienia wcześniejsze, łącznie z warstwą polepy wyznaczającą poziom użytkowy obiektu.

O istnieniu kościoła w XVIII stuleciu, czyli przed wzniesieniem nowego budynku w 1798 r., świadczy dobitnie pięć świeczników ołtarzowych z cyny z inskrypcją: Ecclesia S. Adalberti Zawodie 1748, znalezionych w trakcie remontu w 2018 r., obecnie przechowywanych na plebanii parafii Św. Gotarda (ryc. 4). Forma świeczników wskazuje na ich powstanie po XVI w., gdy zaczęły dominować formy z trójściennymi stopami i tralkowatym cokołem. Brak ornamentacji płaszczyzn stopy zdaje się przesądzać o ich datowaniu na wiek XVIII. Wydaje się zatem, iż inskrypcje umieszczone na jednej ze ścianek stopy poświadczają również czas wykonania świecznika. Pomimo dokładnych oględzin nie stwierdzono znaków cechowych, co wydaje się interesujące. Sugerować to może, iż zostały odlane poza cechową pracownią. Oprócz nich, unikatowym znaleziskiem potwierdzającym istnienie wcześniejszego obiektu sakralnego, jest zespół tablic trumiennych z XVII-XVIII w., które prawdopodobnie były pierwotnie umieszczone na ścianach starszego kościoła. Do wyposażenia świątyni należały prawdopodobnie również malowane, niewielkie wazoniki ceramiczne w typie altarvase, których fragmenty znaleziono w warstwach niwelacyjnych podczas wykopalisk. Były one naśladownictwem podobnych naczyń cynowych, jednak o uproszczonej formie, co przejawia się szczególnie w ukształtowaniu korpusu i uch. Ze względu na kształt uch wyroby można datować je na XVIII w. ${ }^{65}$

Warto też sięgnąć do jeszcze jednego źródła dostarczającego informacji na temat najwcześniejszego kościoła. Jak wspomniałem powyżej, zauważalna jest zmiana orientacji pochówków na cmentarzu przykościelnym. Na podstawie analizy pochówków odsłoniętych w dwóch wykopach (nr 1/59 i 4/2018) po jego stronie północno-zachodniej stwierdzono, iż młodsze groby zorientowane były wzdłuż osi północny zachód-południowy wschód. Wszystkie starsze groby, również te odsłonięte na terenie cmentarza zajętym przez kościół wzniesiony pod koniec XVIII w.

${ }^{65}$ Wołosz A. 1997, s. 392, typ G.11-13; s. 399, typ T.2-7. 
(w wykopach nr 1/2017, 2/2017 i 3/2018), zorientowane są mniej więcej wzdłuż osi północny wschód-południowy zachód, czyli pod kątem ok. $90^{\circ} \mathrm{w}$ stosunku do grobów młodszych (ryc. 5). Taka drastyczna zmiana ich orientacji spowodowana była powstaniem nowego kościoła. Zakładam również, iż starszy obiekt zorientowany był raczej wzdłuż osi północ-południe, z lekkim odchyleniem i skierowaniem prezbiterium w kierunku wschodnim. Wszystkie pochówki, zarówno w pierwszej, jak i w drugiej fazie użytkowania cmentarza, orientowane były nogami w stronę kościoła. Zwyczaj ten zaobserwowany został również na dwóch cmentarzach przykościelnych funkcjonujących do dzisiaj przy obiektach datowanych na XIII w. i XVII w.

Pierwszy z nich to romański kościół w Kotłowie, położony ok. 23 km na południe od Kalisza, na wzniesieniu górującym ponad okolicą. Architektonicznie porównywany bywa z kaliską kolegiatą Św. Pawła na Zawodziu, a datowany jest na trzecią ćwierć XII w. ${ }^{66}$ Tamtejszy przykościelny

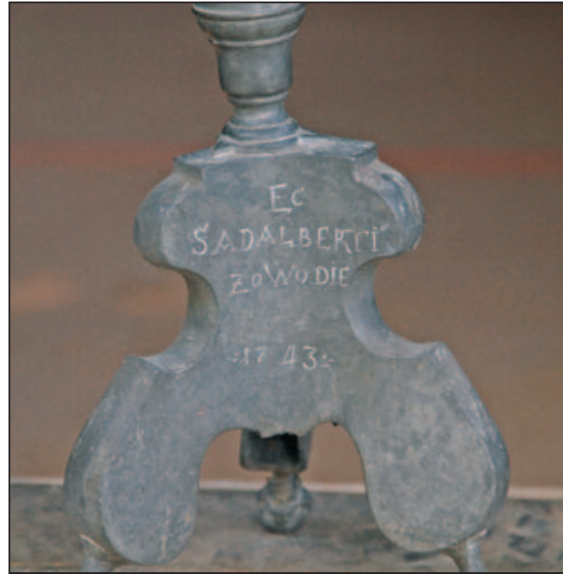

Ryc. 4. Podstawa świecznika z inskrypcją i datą (1743) (fot. D. Wyczółkowski)

Fig. 4. The base of a candlestick with an inscription and date (1743) (photo by D. Wyczółkowski) cmentarz zajmuje stoki wzniesienia. Wszystkie groby do dzisiaj orientowane są w stronę kościoła, a większość zmarłych złożonych jest nogami w stronę świątyni ${ }^{67}$. Drugi z cmentarzy przykościelnych, na którym zaobserwowano podobne ułożenie pochówków, znajduje się w Mikstacie, ok. 3 km na południe od Kotłowa, przy wzniesionym w 1773 r. kościele Św. Rocha. Ponieważ większość przykościelnych cmentarzy została zamknięta już w XIX w., trudno bez gruntownych badań potwierdzić istnienie podobnego zwyczaju na większym terenie. Jednakże już wskazane przypadki pozwalają na przyjęcie, iż analogiczną praktykę stosowano przy kościele Św. Wojciecha na Zawodziu.

Dodatkowym potwierdzeniem zmian, które zaszły w omawianym przypadku, jest źródło kartograficzne — mapa rosyjska ukazująca Kalisz z okolicą, sporządzona w związku ze zjazdem monarchów i wielkimi manewrami prusko-rosyjskimi, które miały miejsce we wrześniu $1835 r{ }^{68}$ Mapa w skali półwiorstowej — 1:21000 cechuje się dużą dokładnością dla terenu Starego Miasta i Zawodzia. Zamieszczono tu charakterystyczne punkty orientacyjne — krzyże przydrożne, grodzisko, a nawet chałupy, które jako zabytkowe dotrwały do naszych czasów. W przypadku świątyni Św. Wojciecha widoczne są duże zmiany dotyczące terenu cmentarza oraz samego kościoła. Jego bryła posadowiona jest według osi północny zachód-południowy wschód, czyli tak, jak można by się spodziewać w przypadku starszej świątyni, biorąc pod uwagę usytuowanie pochówków (ryc. 6). W roku 1835, od blisko 40 lat stał już nowy obiekt, orientowany odmiennie. Można więc całą sprawę uznać za przypadek, lub przyjąć, iż do wyrysowania mapy w 1835 r. użyte były nieznane dzisiaj, wcześniejsze plany Zawodzia i Starego Miasta ${ }^{69}$.

${ }^{66}$ Różański A. 2014, s. 106.

${ }^{67}$ Dobitnie świadczy o tym układ grobowców z tablicami komemoratywnymi. Ich wezgłowie, miejsce gdzie umieszczona jest płyta grobowa z napisami albo tablica i krzyż, znajduje się na krańcu grobu, najbardziej oddalonym od kościoła. Bliższy kościołowi kraniec grobu jest pusty.

68 Bergenstrol. 1835.

${ }^{69}$ Mogły to być np. plany katastralne obu podkaliskich wsi. Na taką możliwość wskazywać może dokładne odwzorowanie układu pól. 


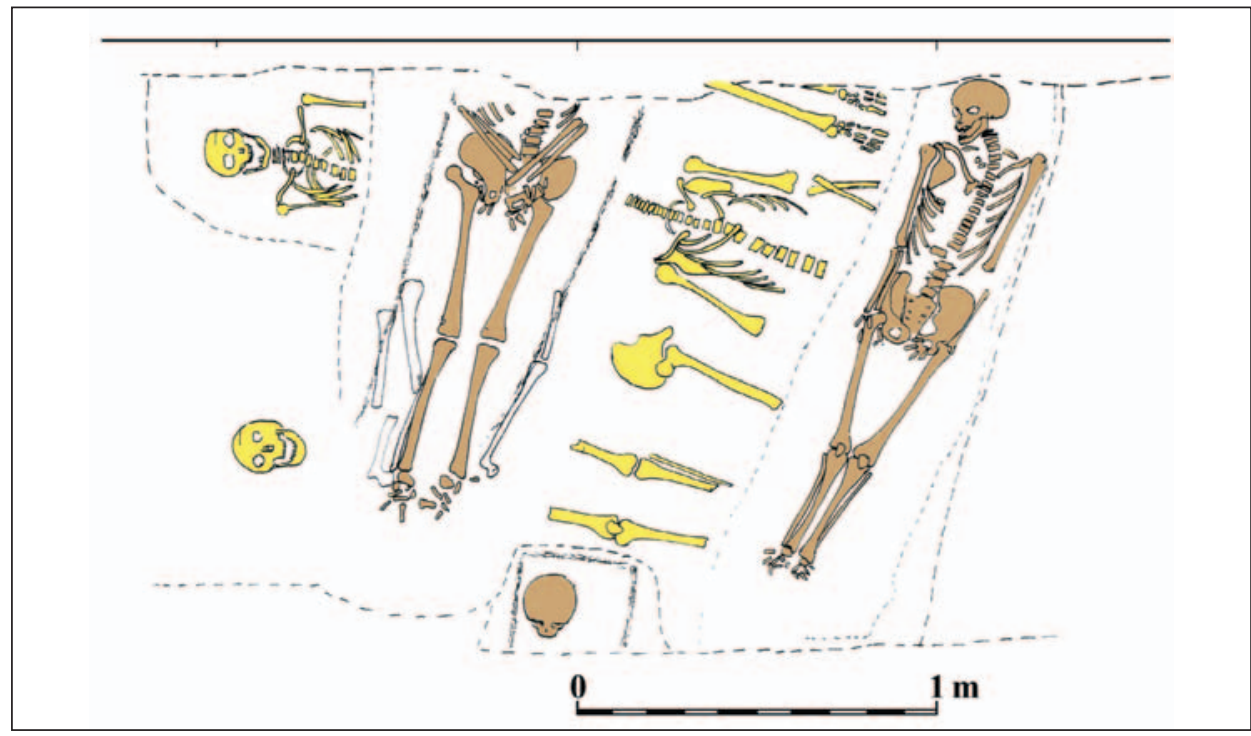

Ryc. 5. Kalisz-Zawodzie. Pochówki w środkowej części wykopu 4/2018: kolor żółty — pochówki z fazy 1 cmentarzyska; kolor brązowy — pochówki z fazy 2 (oprac. D. Wyczółkowski)

Fig. 5. Kalisz-Zawodzie. Burials in the central part of trench 4/2018: yellow - burials from phase 1 of the cemetery; brown — burials from phase 2 (prepared by D. Wyczółkowski)

O zmianach dotyczących terenu cmentarza informują także wyniki nadzorów prowadzonych w 1974 r. w trakcie zakładania kanalizacji w ciągu ulicy Bolesława Pobożnego. W wykopie budowlanym w pobliżu kościoła odsłonięto pochówki niewątpliwie związane z funkcjonowaniem przykościelnego cmentarza. Świadczą one, iż pierwotnie teren cmentarza obejmował także teren dzisiejszej ul. Bolesława Pobożnego. Jednocześnie w całym ciągu ulicy odsłonięto ślady obiektów użytkowanych w okresie wczesnego średniowiecza i w nowożytności. Wskazuje to na znaczne zmiany topografii osady w okresie nowożytnym. Pierwotnie była to osada związana z grodem na Zawodziu. Z samym grodem łączyła ją grobla biegnąca od grodu i dochodząca do terenu osady, na południe od kościoła Św. Wojciecha. Świątynię postawiono na południowo-zachodnim krańcu osady, likwidując znajdujące się tu obiekty mieszkalne. Zawodzie skomunikowane było również układem grobli z sąsiednimi osadami — Stare Miasto i Rajsków. Wydaje się, iż dopiero zmiany koryta Prosny i jej przesunięcie się w kierunku wschodnim umożliwiło bezpośrednie połączenie Zawodzia z osadami na krawędzi doliny. W rezultacie, w okresie nowożytnym wymusiło to zarówno zmianę miejsca posadowienia kościoła, jak i znaczne ograniczenie terenu kościelnego cmentarza od strony północno-wschodniej. Jak wynika z analizy nawarstwień zarejestrowanych w trakcie badań wykopaliskowych w 2018 r., już wcześniej dokonano niwelacji terenu oraz przesunięcia zachodnich i południowo-zachodnich stoków wzniesienia, w celu rozszerzenia terenu cmentarza w tym kierunku. Następnie, po zbudowaniu nowej świątyni, ograniczono teren przykościelnego cmentarza od strony wschodniej i południowo-wschodniej, przeprowadzając nowy ciąg ulicy.

Funkcjonowanie cmentarza przy nowym kościele nie trwało zbyt długo. Przede wszystkim świadczy o tym niewielka liczba grobów datowanych na tę fazę. Z uwagi na brak zabytków 
Ryc. 6. Kalisz-Zawodzie. Fragment mapy

Plan okrestnostej goroda Kališa... z 1835 r. (Bergenstrol 1835): 1 - lokalizacja grodziska; 2 - kościół Św. Wojciecha (oprac. D. Wyczółkowski)

Fig. 6. Kalisz-Zawodzie. A fragment of the map Plan okrestnostej goroda Kališa... from 1835

(Bergenstrol 1835): 1 — the location of the stronghold; 2 - St Adalbert's church (prepared by D. Wyczółkowski)

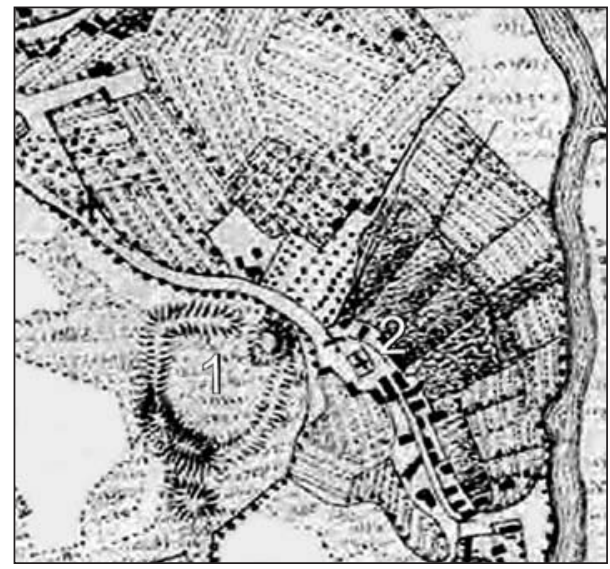

z nimi związanych, trudno je datować bezwzględnie. Tylko jeden z odkrytych pochówków miał wyposażenie i dzięki temu można datować tę fazę cmentarzyska. Były to guziki wojskowe, pochodzące z okresu od ok. połowy XIX w. Przypuszczalnie cmentarz przy nowym kościele był użytkowany od końca XVIII w. do drugiej połowy XIX w. Wtedy, w roku 1870, nastąpiła przebudowa świątyni. W miejsce kruchty o konstrukcji szachulcowej postawiono solidną kruchtę z drewnianych płazów, z chórem muzycznym na piętrze. Wymalowane zostało wnętrze budynku, a gliniane klepisko przesłonięto podłogą z modrzewiowych i sosnowych desek. W tym też czasie teren nekropolii przykryto warstwą gliny, zakrywając wcześniejszą warstwę grzebalną i niwelując teren. Monety znajdowane na powierzchni tej warstwy świadczą o tym, iż działo się to pod koniec XIX stulecia.

Historia kościoła Św. Wojciecha, z powodu ubóstwa źródeł pisanych, w większości dotychczasowych publikacji była spisywana na nowo przez kolejnych badaczy. Większość z nich, posiłkując się wezwaniem kościoła, oraz sugerując się jego drewnianą bryłą, archaiczną w stosunku do wszystkich kaliskich kościołów, uważała kościół Św. Wojciecha za jeden z najstarszych, związanych z tym ośrodkiem. Nie bez znaczenia było sąsiedztwo reliktów kaliskiego grodu. Powtórna analiza źródeł pisanych dotyczących kaliskich fundacji kościelnych, prowadzona w związku z opracowaniem materiałów z badań archeologicznych na Zawodziu, dała podstawy do sformułowania nowych hipotez badawczych. Zgodnie z interpretacją źródeł pisanych, początek kościoła należałoby widzieć nie później niż w końcu XIII w. Jednocześnie, w sposób nie podlegający dyskusji wykazano, iż kościół Św. Wojciecha nigdy nie był świątynią parafialną, lecz był kościołem rektorskim na terenie parafii Najświętszej Panny Marii w Kaliszu. O jego początku świadczą najprecyzyjniej wyniki badań wykopaliskowych przeprowadzonych w latach 2017 i 2018. Prace te objęły zarówno wnętrze budowli, jak i teren przykościelnego cmentarza. Opracowanie zgromadzonych informacji i pozyskanych materiałów oraz prowadzona równolegle ponowna analiza zabytków z badań archeologicznych z 1959 r., dostarczyły kolejnych dowodów. Świadczą one o pierwotnym zasiedleniu tego terenu co najmniej od połowy X w. do XII w. Przesuwanie datowania końca tego osadnictwa na cały wiek XIII, pomimo przesłanek zawartych w źródłach pisanych, budzi jednak wątpliwości wobec niedostatku znalezisk archeologicznych i fragmentaryczności badań terenowych. Równocześnie wyniki analizy zabytków oraz układów stratygraficznych wskazują na możliwość określenia czasu powstania pierwszej świątyni najwcześniej na drugą połowę XII w. Analiza układu po- 
chówków dwóch faz cmentarza doprowadziła do sformułowania tezy o zmianie osi założenia w trakcie budowy nowego budynku kościoła u schyłku XVIII stulecia.

Adres Autora:

mgr Dariusz Wyczółkowski

Instytut Archeologii i Etnologii PAN

Al. Solidarności 105

00-140 Warszawa

darekw@iaepan.edu.pl

https://orcid.org/0000-0003-4856-684X

\section{BIBLIOGRAFIA}

Baliński Michał, Lipiński Tymoteusz. 1843. Starożytna Polska pod względem historycznym, jeograficznym i statystycznym opisana, t. 1, wyd. 1, Warszawa.

Baranowski Tadeusz. 2010. Kalisia. Dlaczego można identyfikować Kalisia Ptolemeusza z Kaliszem nad Prosna?, [w:] Od Kalisii do Kalisza. Skarby doliny Prosny. Katalog wystawy, Zamek Królewski w Warszawie, 30 kwietnia 2010-30 maja 2010, red. S. Suchodolski, M. Zawadzki, Warszawa, s. 95-99.

Biernacki Cezar Augustyn. 1848. Opis miasta Kalisza, „Przegląd Naukowy”, R. 7, nr 17-18, s. 265-271.

Błachowicz Maciej. 2008. Opowiesśc zapisana w sosnowym drewnie, „Kalisia Nowa”, nr 5-8, s. 24-26.

Bergenstrol. 1835. Plan okrestnostej goroda Kališa, Plan des environs de Kalisz, Instrumentalno sniatyj pod rukawodstwom Genieralnego Sztaba, Sztabs Kapitana Bergenstrola, Petersburg, skala 1:21000.

Chapman Emma Rosamund. 2016. Children and child burial in medieval England (Doctoral thesis), https://doi.org/10.17863/CAM.15979 (dostęp 28.06.2021).

Chodyński Adam. 1872. Kalisz dawny i teraźniejszy. Opis topograficzno-historyczny (Ciąg drugi), I: Kalisz Mieczysławowski, „Kaliszanin”, nr 3/48 (6/18 czerwca), s. 191.

Chodyński Adam. 1885. Kieszonkowa kroniczka historyczna miasta Kalisza ułożona przez Adama Chodyńskiego, Kalisz.

Chodyński Adam. 1901. Zawodzie i kościółek św. Wojciecha, „Gazeta Kaliska”, nr IX/78 (24 marca/ 6 kwietnia), s. 2-3.

Craig-Atkins Elisabeth. 2014. Eavesdropping on short lives: Eaves-drip burial and the differential treatment of children one year of age and under in early Christian cemeteries, [w:] Medieval Childhood: archaeological approaches, red. D.M. Hadley, K.A. Hemer, Oxbow, s. 95-113.

Crow Madison, Zori Colleen, Zori Davide. 2020. Doctrinal and Physical Marginality in Christian Death: The Burial of Unbaptized Infants in Medieval Italy, „Religions”, t. 11, nr 12, s. 678, https://doi.org/10.3390/rel11120678 (dostęp 26.08.2021).

Dąbrowski Krzysztof. 1962. Badania archeologiczne na Zawodziu (1959-1960), [w:] Osiemnaście wieków Kalisza. Studia i materiały do dziejów miasta Kalisza i regionu kaliskiego, red. A. Gieysztor, K. Dąbrowski, t. 3, Kalisz, s. 53-90.

Dąbrowski Krzysztof. 1977. Kalisz od zarania dziejów do wczesnego średniowiecza, [w:] Dzieje Kalisza, red. W. Rusiński, Poznań, s. 17-43.

Dąbrowski Krzysztof, Gieysztor Aleksander. 1964, Kalisz, [w:] Słownik Starożytności Stowiańskich. Encyklopedyczny zarys kultury Stowian od czasów najdawniejszych do schyłku wieku XII, t. II: F-K, red. W. Kowalenko, G. Labuda, T. Lehr-Spławiński, Warszawa, s. 353-356.

Delimata Małgorzata. 2004. Rytuał pogrzebowy dzieci w Polsce średniowiecznej $i$ wczesnonowożytnej, [w:] Dusza maluczka, a strata ogromna. Funeralia Lednickie. Spotkanie 6, red. W. Dzieduszycki, J. Wrzesiński, Poznań, s. 99-102. 
Grzesik Ryszard. 2002. Święty Wojciech w środkowoeuropejskiej tradycji hagiograficznej i historycznej, „Studia Źródłoznawcze”, t. 40, s. 43-56.

Hausmair Barbara. 2017. Topographies of the afterlife: Reconsidering infant burials in medieval mortuary space, ,Journal of Social Archaeology”, R. 17, z. 2, s. 210-236, http://nbn-resolving.de/ urn:nbn:de:bsz:352-0-405795 (dostęp 28.06.2021).

Hausmair Barbara. 2019. Traufkinder' im Mittelalter? Überlegungen zu Kleinkindbestattungen, Taufstatus und einem populären Deutungsansatz, [w:] Leben mit dem Tod. Der Umgang mit Sterblichkeit in Mittelalter und Neuzeit, red. T. Kühtreiber, R. Risy, G. Scharrer-Liška, C. Theune, Beitrage zur Mittelalterarchäologie in Österreich, t. 35, Wien, s. 150-166.

Kalisz. 1902. Kalisz, [w:] Slownik Geograficzny Królestwa Polskiego i innych krajów słowiańskich, t. XV, cz. II, red. B. Chlebowski, J. Krzywicki, Warszawa, s. 41-44.

Kieling Michał, Kęszka Sławomir, Splitt Jerzy. 2016. Diecezja Kaliska. Parafie, kościoły, kaplice. Przeszłość i teraźniejszość, Kalisz.

Kędzierski Adam, Malarczyk Dorota, Wyczółkowski Dariusz. 2020. Recent Finds of Islamic Coins from the Old Town and Zawodzie Districts in Kalisz, „Notae Numismaticae”, t. 15, s. 21-39.

KDW. 1877. Kodeks Dyplomatyczny Wielkopolski, t. I, red. I. Zakrzewski, Poznań.

KDW. 1878. Kodeks Dyplomatyczny Wielkopolski, t. II, red. I. Zakrzewski, Poznań.

KDW. 1881. Kodeks Dyplomatyczny Wielkopolski, t. IV, red. I. Zakrzewski, Poznań.

KDW. 1982. Kodeks Dyplomatyczny Wielkopolski, t. VI, red. A. Gąsiorowski, H. Kowalewicz, Warszawa-Poznań.

KDW. 1999. Kodeks Dyplomatyczny Wielkopolski, t. XI, red. A. Gąsiorowski, T. Jasiński, T. Jurek, I. Skierska, Poznań.

Kobyliński Piotr. 1865. Kalisz pod względem religijnym z głównym poglądem na kolegiatę, „Tygodnik Katolicki”, t. 6, nr 50, s. 453-458.

Kolendo Jerzy. 2010a. Gdzie powinna być lokalizowana Kalisia Ptolemeusza, [w:] Od Kalisii do Kalisza. Skarby doliny Prosny. Katalog wystawy, Zamek Królewski w Warszawie, 30 kwietnia 2010 - 30 maja 2010, red. S. Suchodolski, M. Zawadzki, Warszawa, s. 91-94.

Kolendo Jerzy. 2010b. Kalisia i Leukaristos: dwa „miasta” w „Geografii” Ptolemeusza i zagadnienie wspótrzędnych geograficznych w „Wielkiej Germanii”, „Światowid”, t. 8 (49), 2009/2010, nr B, s. 77-87.

Kronika Wielkopolska. 1970. Kronika Wielkopolska, oprac. B. Kürbis, Pomniki dziejowe Polski, t. 7, Warszawa.

Krzyżanowski Stanisław. 1890. Dyplomy i kancelaria Przemysława II studium z dyplomatyki polskiej 13 wieku, [w:] Pamiętnik Akademii Umiejętności w Krakowie. Wydział Filologiczny i HistorycznoFilozoficzny, nr 8, Kraków, s. 122-192.

Młynarska Marta. 1960. Proces lokacji Kalisza w XIII w. i w pierwszej połowie XIV w., [w:] Osiemnaście wieków Kalisza. Studia i materiały do dziejów miasta Kalisza i regionu kaliskiego, t. I, red. A. Gieysztor, K. Dąbrowski, Kalisz, s. 103-130.

Raciborski Józef. 1912. Monografja Kalisza, cz. 1, Kalisz.

Różański Artur. 2014. Kalisz i Kotłów — dwie południowowielkopolskie świątynie doby Mieszka III. Oryginat i kopia czy tylko przypadkowa analogia?, [w:] Średniowieczna architektura sakralna w Polsce w świetle najnowszych badań, red. T. Janiak, D. Stryniak, Gniezno, s. 89-108.

Stawecki Edward. 1858. Album Kaliskie ułożone i opisane przez Edwarda Staweckiego. Rysunki S. Barcikowskiego N. S. W. R. Litografja M. Fajansa. Serja I. zawierająca widoki samego miasta Kalisza, Warszawa.

Trawkowski Stanisław. 1962. Geneza regionu kaliskiego, [w:] Osiemnaście wieków Kalisza. Studia i materiały do dziejów miasta Kalisza i regionu kaliskiego, t. 3, red. A. Gieysztor, K. Dąbrowski, Kalisz, s. 7-51.

Ulrich-Bochsler Susi. 1996. Kirchengrabungen - wichtiger Fundus für Archäologie und Anthropologie, „Archäologie der Schweiz”, t. 19, s. 162-166. 
Unger Josef. 2002. Pohřební ritus a zacházení s těly zemřelých v českých zemích (s analogiemi i jinde v Evropě) v 1.-16. Století, Panoráma biologické a sociokulturní antropologie, t. 9, red. J. Malina, Brno.

Uzdowska Teresa. 1956. Kalisz we wczesnym średniowieczu, [w:] K. Dąbrowski, T. Uzdowska, M. Młynarska, Kalisz w starożytności i w średniowieczu, Popularnonaukowa Biblioteka Archeologiczna, nr 1, Warszawa-Wrocław, s. 42-62.

Wąsowiczówna Teresa. 1960. Kalisz na tle wczesnośredniowiecznej sieci drogowej, [w:] Osiemnaście wieków Kalisza. Studia i materiały do dziejów miasta Kalisza i regionu kaliskiego, t. 1, red. A. Gieysztor, K. Dąbrowski, Kalisz, s. 69-101.

Wędzki Andrzej. 1977. Kalisz w państwie wczesnopiastowskim i w okresie rozbicia feudalnego, [w:] Dzieje Kalisza, red. W. Rusiński, Poznań, s. 44-62.

Wołosz Artur. 1997. Cynowe wazoniki ołtarzowe (altarvasen) — próba określenia typologii oraz chronologii obiektów z warsztatów konwisarzy gdańskich, malborskich i toruńskich XVII-XVIII wieku, „Rocznik Olsztyński”, R. 17, s. 379-414.

Zawodzie. 1895. [w:] Stownik Geograficzny Królestwa Polskiego i innych krajów słowiańskich, t. 14, red. B. Chlebowski, J. Krzywicki, Warszawa, s. 498-499.

Ziąbka Leszek, Kędzierski Adam. 2016. Wyniki badań archeologicznych prowadzonych podczas prac remontowo-konserwatorskich kościoła św. Wojciecha na Zawodziu, „Rocznik Kaliski”, t. 42, s. 249-263.

\section{Strony internetowe}

Kościół. 2020. Kościót św. Wojciecha w Kaliszu, https://pl.wikipedia.org/wiki/Kościół_św._Wojciecha_ w_Kaliszu (dostęp 28.06.2021).

Splitt J. A. 2009. Kościót pw. św. Wojciecha na Zawodziu, [w:] Dawny Kalisz. www.kalisz.info, www.kalisz.info/go_swwojciech.php (dostęp 28.06.2021).

\section{The mediaeval church of St Adalbert at Zawodzie in Kalisz - research and interpretations}

St Adalbert's church at Zawodzie in Kalisz was one of the oldest religious foundations in that town. From the mid-19th c. authors writing on the history of the town stressed the antiquity of the church, linking its origins with the legendary stay of St Adalbert in Kalisz. The thesis about the ancient origin of the church and the parish was supported by using a range of sources, interpreted in accordance with the previously made assumptions. In the 20th c. no attempt was made to reinterpret the available written sources, and analyses were based on the dedication of the church and the history of the early settlement.

The excavations conducted around the church in 1959 were not properly documented and their results were not taken into account in later publications. However, results of recent excavations (2017-2018) prove without any doubt that the church was founded later that it was assumed. A new analysis of written sources has shown that as late as in the 1290s Zawodzie was owned by the duke while the church was first mentioned in 1292. Archaeological finds indicate that the church was built in the location of a settlement that had still functioned in the 12th c., and the features uncovered can be dated to the 13th c. Written sources contradict the existence of a separate parish in this place, confirming that it was connected with The Holy Virgin parish.

Translated by

Izabela Szymańska 